\title{
Laboratory study of the effects of leek lectin (APA) in transgenic tobacco plants on the development of cotton leafworm Spodoptera littoralis (Lepidoptera: Noctuidae)
}

\author{
Amin SADEGHI ${ }^{1,2}$, Guy SMAGGHE ${ }^{1 *}$, EsMERALDA JURADO-JÁCOME ${ }^{2 * *}$, WiLLY J. PEUMANS ${ }^{2}$ \\ and ELS J.M. VAN DAMME ${ }^{2}$ \\ ${ }^{1}$ Laboratory of Agrozoology, Department of Crop Protection, Faculty of Bioscience Engineering, Ghent University, \\ Coupure Links 653, B-9000 Gent, Belgium \\ ${ }^{2}$ Laboratory of Biochemistry and Glycobiology, Department of Molecular Biotechnology, Faculty of Bioscience Engineering, \\ Ghent University, Coupure Links 653, B-9000 Gent, Belgium
}

Key words. Allium porrum, Alliaceae, insect resistance, lectin, Lepidoptera, Spodoptera littoralis, transgenic tobacco plant, weight decrease

\begin{abstract}
Transgenic tobacco plants expressing the Allium porrum L. (leek) agglutinin (called APA) under the control of the 35S constitutive promoter were tested for their insecticidal activity against the cotton leafworm, Spodoptera littoralis (Lepidoptera: Noctuidae). Southern blot and PCR analysis confirmed that the APA gene was integrated into the plant genome. Northern and Western blots as well as semi-quantitative agglutination assays revealed lectin expression at various levels in the transgenic lines. Biochemical analyses indicated that the recombinant APA has the same molecular structure as the native lectin. Native and recombinant lectin have the same N-terminal amino acid sequence. Bioassays using detached leaves from transgenic tobacco plants demonstrated that the ectopically expressed APA significantly $(\mathrm{p}<0.05)$ reduced the weight gain of 2 nd-instar larvae of $S$. littoralis. This inhibitory effect was observed throughout the experiment and on day 11 the caterpillars fed on transgenic tobacco leaves were $25-30 \%$ lighter in weight than the control caterpillars fed on wild type plants. In addition the lectin retarded the development of the larvae and metamorphosis, reduced pupal weight and increased mortality rate. These findings suggest that APA is a suitable insect resistance protein for integrating into plant genomes for controlling S. littoralis.
\end{abstract}

\section{INTRODUCTION}

Considerable progress has been made over the last two decades in the production of transgenic plants that express foreign genes. However, genetic engineering of plants for insect pest control is mainly based on the ectopic expression of genes encoding toxins. The bacterial $\delta$-endotoxins from Bacillus thuringiensis (Bt) have received special attention (Sharma et al., 2004). In spite of the tremendous positive effect of this new bioinsecticide on pest control, there are growing concerns about both the safety of these genetically modified crops for the consumer (Shelton et al., 2002) and the development of resistance to $B t$ toxin in insect populations (Sanchis \& Bourguet, 2008). Therefore, there is a growing interest in the development of alternative strategies based on the use of plant defense proteins such as plant lectins and proteinase inhibitors for plant protection purposes (Chen, 2008). The underlying idea is to exploit the plant's own defense mechanisms either by altering the expression of their endogenous defense proteins or by introducing insect control genes from unrelated species of plants.

During the last two decades, numerous reports have been published dealing with the insecticidal activity of plant lectins against many pest insects belonging to the orders Lepidoptera, Coleoptera, Diptera and Hemiptera (Vasconcelos \& Oliveira, 2004). In vitro assays, in which purified lectins were added to an artificial diet as well as in vivo assays with transgenic plants expressing a foreign lectin gene clearly demonstrate the potential of several plant lectins as insecticidal proteins (Sadeghi et al., 2007, 2008 , in press).

One example of such an insecticidal protein is the Galanthus nivalis (snowdrop) agglutinin (GNA) (Van Damme et al., 1991). Over the last few years numerous studies have shown that GNA and GNA-related lectins are toxic especially to sap-sucking insects. The GNA gene has been incorporated into tobacco, wheat, tomato, potato and rice to confer resistance to aphids and leafhoppers (Jouanin et al., 1998). In addition, GNA has also been shown to have a detrimental effect on the larval growth and development of several Lepidoptera, e.g. tomato moth (Lacanobia oleracea) and Mexican rice borer (Eoreuma loftini), fed treated artificial diets or transgenic plants (Fitches et al., 1997; Gatehouse et al., 1997; Sétamou et al., 2003). Though GNA is certainly a promising insecticidal protein there is currently an intensive search for possible superior alternatives within the

\footnotetext{
* Corresponding author; e-mail: guy.smagghe@ugent.be

** Present address: Institute of Biology Leiden-IBL, Section of Molecular and Developmental Genetics, Leiden University. Clusius Laboratory, Wassenaarseweg 64, 2333 AL Leiden, The Netherlands
} 
same lectin family. Comparative analyses indicate that some GNA-related lectins found in Alliaceae species are substantially more active than GNA itself in terms of specific agglutination activity and antiviral activity against human immunodeficiency virus. Since one can reasonably assume that the insecticidal activity of GNA and related lectins is somehow related to their sugar-binding activity/specificity it seemed worth checking whether the higher in vitro activities of some Alliaceae lectins possibly result in an increased insecticidal potency. In addition, the fact that a lectin is found in a vegetable may contribute towards an easier acceptance as an insect resistance factor in transgenic crop plants. Based on these considerations the leaf lectin from leek (Allium porrum agglutinin or APA) was chosen for consideration as a likely insecticidal protein.

Although the exact mechanism by which lectins affect insects is still unknown, it seems that their toxicity is at least partly due to destabilization of insect metabolism by interfering with gut enzymes either indirectly or through specific binding to receptors in the gut of the insect, or interference with the peritrophic membrane and digestive enzymes.

The present paper reports the construction and characterisation of transgenic tobacco plants expressing leek lectin. In addition, we report the insecticidal activity of APA expressed in leaves of transgenic tobacco plants on the development of larvae of the cotton leafworm, Spodoptera littoralis. This polyphagous noctuid species is an agriculturally and horticulturally economically important caterpillar, which damages at least 87 crop species belonging to 40 families distributed all over the world (Alford, 2000).

\section{MATERIAL AND METHODS}

\section{Plant material and growth conditions}

Tobacco seeds were surface-sterilized by consecutive treatments with a solution of $70 \%$ ethanol and $7 \%(\mathrm{v} / \mathrm{v}) \mathrm{NaOCl}$, and thoroughly rinsed with sterile water. For an in vitro culture, seeds were placed on top of solid medium of Murashige \& Skoog (MS) (1962), containing 4.3 g/l MS micro and macro nutrients containing vitamins (Duchefa, Haarlem, the Netherlands), $30 \mathrm{~g} / 1$ sucrose and $8 \mathrm{~g} / 1$ plant agar (Duchefa). The $\mathrm{pH}$ of the medium was adjusted to 5.7 with $0.5 \mathrm{M} \mathrm{NaOH}$ prior to adding agar. After germination the plants were transferred onto MS medium containing $2.15 \mathrm{~g} / 1$ micro and macronutrients and vitamins.

Transgenic tobacco seeds were germinated in commercial pot soil (Structural type 0, M. Snebbout n.v./s.a., Kaprijke, Belgium). Plants were grown in a chamber at $25^{\circ} \mathrm{C}$ and a $16 \mathrm{~h}$ photoperiod. When the plants reached a height of $30 \mathrm{~cm}$ (approx. 10 weeks after sowing) they were used for insect bioassays.

\section{Plasmid construction}

Plasmids were constructed with the full-length coding sequence of LECAPA, the cDNA encoding APA (GenBank accession number L12173). This sequence was amplified by PCR using the primers 5'-GCGCTCTAGAATGGGCCGTACT ACTCCATCT-3' (5' primer with added XbaI site) and 5'GCGCCTGCAGTCAAGCAGCACTGGTACCAAC-3' primer with added PstI site). The restricted PCR fragments were subcloned in the $X b a \mathrm{I}$ and Pst I sites of the expression cassette of the vector pFF19 (Timmermans et al., 1990) resulting in plasmid pAP19. The sequence of the PCR fragment was verified by DNA sequencing (Sanger et al., 1977). A complete expression cassette from pAP19 with a correct APA sequence containing the $35 \mathrm{~S}$ CaMV enhancer, promoter and polyadenylation sequences was inserted between the EcoRI and HindIII restriction sites located between the right and left border of the T-DNA of the binary vector pGPTV-KAN (Becker et al., 1992). The resulting pGPTV-KAN/LECAPA1 plasmid was transferred into Agrobacterium tumefaciens GV3101 by electroporation and used for plant transformation.

\section{Transformation of Nicotiana tabacum and molecular analysis of transformants}

Transformation of tobacco (N. tabacum L. cv. Wisconsin 38) plants was performed using the leaf disc co-cultivation method (Horsch et al., 1985). Selection of transgenic shoots was performed on MS-medium containing $300 \mathrm{mg} / 1$ kanamycin sulphate, $100 \mathrm{mg} / \mathrm{l}$ carbenicillin and $100 \mathrm{mg} / \mathrm{l}$ cefotaxime. Independent kanamycin resistant tobacco lines obtained after transformation were screened for the presence of the introduced sequences by PCR amplification using genomic DNA from all transgenic lines and two primers derived from the $N$ - and $C$-terminal sequence of APA. Only the PCR positive plants were further analysed at the RNA and protein level.

RNA analysis was performed on transgenic plants of both the $\mathrm{T}_{0^{-}}$and the $\mathrm{T}_{1}$-generation as described by Desmyter et al. (2003). Approximately $40 \mu \mathrm{g}$ of total RNA was denaturated with glyoxal and dimethylsulfoxide and analyzed on a $1.2 \%$ (w/v) agarose gel. For Northern blot analysis membranes were probed with random-primer-labelled cDNAs encoding APA or labelled oligonucleotide complementary to LECAPA coding sequence as described previously (Van Damme et al., 1993). DNA blots were performed using the standard protocol as described by Sambrook et al. (1989). Southern hybridization was performed according to Church \& Gilbert (1984) using a random-primer-labelled cDNA encoding APA as a probe.

\section{Preparation of crude extracts}

Tobacco leaves were homogenized in $20 \mathrm{mM}$ unbuffered 1,3-diaminopropane at $5 \mathrm{ml} / \mathrm{g}$ fresh weight (FW) using a mortar and pestle. Extracts were transferred into microcentrifuge tubes and centrifuged $(13,000 \times g ; 5 \mathrm{~min})$. The supernatants were collected and used for further analyses. The total protein content was determined according to the Bradford assay (Biorad, Hercules, CA, USA) (Bradford, 1976) using plant proteins (Robinia lectin and bean lectin) as a standard. The latter lectins were purified in house using purification schemes described previously (Van Damme et al., 1998).

\section{Western blot analysis}

Western blot analysis was performed on transgenic plants of both the $T_{0}$ - and the $T_{1}$-generation as described by Desmyter et al. (2003). Aliquots of the extracts containing $40 \mu \mathrm{g}$ soluble leaf proteins were separated by SDS-PAGE on a $15 \%$ polyacrylamide gel using mini-PROTEAN ${ }^{\circledR} 3$ electrophoresis module from BioRad (Laemmli, 1970). Blotting and immunodetection of the proteins was performed as described by Desmyter et al. (2001). Polyclonal antibodies specifically directed against the closely related garlic leaf lectin (Smeets et al., 1997) were used to detect APA in transgenic plants.

\section{Purification of recombinant APA}

Approximately $1 \mathrm{~kg}$ of transgenic tobacco leaves was homogenised in 51 of $20 \mathrm{mM} \mathrm{1,3-diamino} \mathrm{propane} \mathrm{containing}$ $0.01 \%(\mathrm{w} / \mathrm{v})$ thiourea using a Waring blender. The crude extract 
was cleared by centrifugation at $3,000 \mathrm{~g}$ for $10 \mathrm{~min}$ and filtered through Whatman $3 \mathrm{MM}$ filter paper. The extract was then applied onto a column $(5 \mathrm{~cm} \times 5 \mathrm{~cm}$; approximately $100 \mathrm{ml}$ bed volume) of Q Fast Flow equilibrated with $20 \mathrm{mM}$ 1,3-diamino propane. After washing the column with $20 \mathrm{mM}$ 1,3-diamino propane until the $\mathrm{A}_{280}$ fell below 0.1 , bound proteins were desorbed with $500 \mathrm{ml}$ of $0.1 \mathrm{M}$ Tris- $\mathrm{HCl} \mathrm{pH} 8.7$ containing $0.4 \mathrm{M}$ sodium chloride. After adjusting the $\mathrm{pH}$ to 7.5 with $1 \mathrm{~N}$ $\mathrm{HCl}$ the partially purified protein fraction was placed on a column $(1.6 \times 10 \mathrm{~cm} ; 20 \mathrm{ml}$ bed volume $)$ of mannose-Sepharose 4B equilibrated with $0.4 \mathrm{M}$ sodium chloride. After washing the column with $0.4 \mathrm{M}$ sodium chloride, the bound proteins were eluted with $100 \mathrm{ml}$ of $20 \mathrm{mM}$ unbuffered 1,3-diamino propane. The eluate was adjusted to $\mathrm{pH} 7.5$ with $0.1 \mathrm{M} \mathrm{HCl}$ and the $\mathrm{NaCl}$ content increased to $0.4 \mathrm{M}$ by adding solid salt. After standing for one hour the solution was centrifuged $(3,000 \mathrm{~g}$ for $10 \mathrm{~min})$ and the supernatant added on the same column of mannoseSepharose 4B for a second affinity chromatography. The lectin was eluted with $20 \mathrm{mM}$ unbuffered 1,3-diamino propane, dialyzed against water and stored at $-20^{\circ} \mathrm{C}$ until required.

\section{Hemagglutination assays}

Agglutination assays were carried out in small glass tubes in a final volume of $50 \mu \mathrm{l}$ containing $10 \mu \mathrm{l}$ of extracts or lectin solutions, $10 \mu \mathrm{l}$ of $1 \mathrm{M}$ ammonium sulphate and $30 \mu \mathrm{l}$ of a $2 \%$ suspension of trypsin-treated rabbit erythrocytes (made up in phosphate buffered saline: $137 \mathrm{mM} \mathrm{NaCl}, 8 \mathrm{mM} \mathrm{Na}_{2} \mathrm{HPO}_{4} \cdot 2 \mathrm{H}_{2} \mathrm{O}, 3$ $\mathrm{mM} \mathrm{KCl}, 1.5 \mathrm{mM} \mathrm{K \textrm {K } _ { 2 }} \mathrm{PO}_{4}$ ). Erythrocytes were treated with trypsin as described previously (Van Damme et al., 1987). The lectin concentration in the crude extracts was estimated by a semi-quantitative agglutination assay. Ten $\mu 1$ aliquots of serially 2-fold diluted (in $1 \mathrm{M}$ ammonium sulphate) extracts were mixed with $40 \mu 1$ of a $2 \%$ suspension of trypsin-treated rabbit erythrocytes in the wells of polystyrene 96 U-welled microtiter plates. Agglutination was assessed visually after incubation for $1 \mathrm{~h}$ at room temperature. A serially diluted solution of purified APA of known concentration was included to estimate the absolute lectin content in the extracts. The detection limit of this semiquantitative method is approximately $0.25 \mu \mathrm{g} / \mathrm{ml}$.

\section{Analytical techniques}

Recombinant APA was analyzed using SDS-PAGE and electroblotted on a polyvinylidene difluoride membrane. The protein was excised from the blot and sequenced on an Applied Biosystems Procise 491 cLC protein sequencer (Applied Biosystems, Foster City, CA, USA).

Prior to mass spectrometry, proteins were desalted on a C4ZipTip (Millipore, Bedford, MA, USA). Proteins were dissolved in $50 \%(\mathrm{v} / \mathrm{v})$ water $/ 50 \%(\mathrm{v} / \mathrm{v})$ acetonitrile containing $0.1 \%$ acetic acid and injected at $5 \mu \mathrm{l} / \mathrm{min}$ on an electrospray ion trap Esquire-LC-MS mass spectrometer (Bruker Daltonic, Bremen, Germany). About 300 spectra were averaged resulting in an accuracy of $0.01 \%$ for proteins with a relative molecular mass of 10,000 .

Gel filtration analysis of purified leek lectin was done on a Pharmacia Superose 12 column equilibrated with phosphatebuffered saline containing $0.2 \mathrm{M}$ mannose and $0.2 \mathrm{M}$ galactose to prevent the lectin binding to the column. Around $400 \mu \mathrm{g}$ of the lectin was loaded on the column. The flow rate was $20 \mathrm{ml} / \mathrm{h}$. Molecular mass reference markers were Sambucus nigra lectin related protein $(60 \mathrm{kDa})$, Galanthus nivalis agglutinin $(50 \mathrm{kDa})$ and banana lectin $(30 \mathrm{kDa})$.

\section{Insects}

Newly moulted $\left(0-6\right.$ h) $2^{\text {nd }}$ instar larvae of $S$. littoralis originated from a continuous stock colony in the Laboratory of Agrozoology at Ghent University, Belgium, which was kept at $23-25^{\circ} \mathrm{C} ; 65-70 \%$ relative humidity and a $16 \mathrm{~L}: 8 \mathrm{D}$ photoperiod as described previously (Smagghe et al., 2002; Hakim et al., 2007).

\section{Insect bioassay using detached leaves}

A typical cage was constructed using polyethylene containers ( $9 \mathrm{~cm}$ in diameter, $3 \mathrm{~cm}$ in height) as described by Van de Veire et al. (1996). Six air holes (5 mm in diameter) were drilled in the wall of the container and covered by net cloth for ventilation. In addition, one channel $(5 \mathrm{~mm}$ in diameter) was drilled for the leaf petiole, which was placed in water. The top of the cup was covered with a piece of the same polyethylene. The cages were kept in the same conditions as cited above.

Detached leaves of transgenic tobacco plants expressing APA and wild type tobacco plants (control) were placed in the experimental cages. The bioassay was started with newly ecdysed (0-6 h old) 2nd instar larvae of $S$. littoralis that originated from the laboratory culture. Larvae were fed daily on freshly excised leaves and excrements were removed from the cages. For each transgenic line and wild type (control) tobacco plants 18 second-instar larvae were used. Per treatment we analysed 3 randomly chosen replicate groups of 6 cages with each cage containing one larva. At 1-2 day-intervals, insect survival was evaluated and used as an indicator of the toxicity of the leaves for cotton leafworm. In addition, larval weight gain and percentage and time of pupation as well as adult formation/emergence were scored as biological endpoints indicating sublethal effects as described in Sadeghi et al. (2008).

\section{Statistical analysis}

For each transgenic line and the control, data are expressed as means \pm SEM based on 18 individual measurements. Percentage reduction in weight gain of the larvae fed on the transgenic lines expressing APA was based on the formula: percentage reduction in weight gain $=[(\mathrm{C}-\mathrm{T}) / \mathrm{C}] \times 100$, where $\mathrm{C}=$ weight gain of larvae feeding on control (wild type) plant and $\mathrm{T}=$ weight gain of larvae feeding on transgenic plants (Huang et al., 2006). To detect significant differences between treatments and separate mean larval fresh weights, analysis of variance (ANOVA) and subsequent post hoc Duncan test with $p=0.05$ were employed in SPSS 12 (SPSS Inc., Chicago, IL, USA). The total mortality for each treatment was corrected using Abbott's formula (1925), which is based on the mortality recorded for the wild type (control) plants.

\section{RESULTS}

\section{Expression of APA in transgenic tobacco}

Tobacco ( $N$. tabacum L. cv. Wisconsin 38) leaf discs were transformed with Agrobacterium tumefaciens GV3101 harbouring the lectin construct pGPTV-KAN/ LECAPA1 under the control of the $35 \mathrm{~S}$ constitutive promoter. All plants obtained after transformation were analysed by PCR to verify the presence of the APA coding sequence in the tobacco genome. In approximately $88 \%$ of all kanamycin-resistant plants selected the presence of the APA gene could be shown by PCR. Only those plants that were positive in the PCR analysis were withheld for further analysis. For a selection of transgenic lines the presence of the T-DNA in the genome was also confirmed by Southern blot analysis. The number of inserted copies varied from 1 to 3 . No signal was detected for the untransformed tobacco plant (data not shown).

The expression of the lectin transgene was examined by analysing all transgenic lines ( $\mathrm{T}_{0}$ generation) at the RNA 


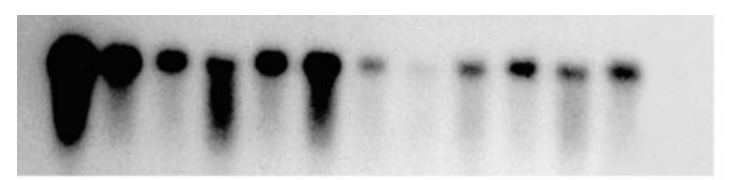

$800 \mathrm{bp}$

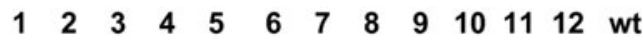

Fig. 1. Northern blot analysis of total RNA from 12 transgenic lines and one control plant. Approximately $40 \mu \mathrm{g}$ of total RNA was analyzed on gel and hybridized with ${ }^{32} \mathrm{P}$ labelled oligonucleotide complementary tot LECAPA coding sequence. Lanes 1-12 show the results for 12 transgenic lines; lane wt shows RNA sample from wild type plant. Lanes 1, 3, 4 and 10 show the results for transgenic lines APA-1, APA-2, APA-3 and APA-4.

and protein level. Transcription products of predicted size were detected in approximately $57 \%$ of the transformants but not in wild-type plants (Fig. 1). Western blot analysis of crude leaf extracts confirmed that most of these transformants contained immunoreactive bands. In addition, crude leaf extracts from 50 in vitro established plants were analyzed for their agglutinating activity against trypsin-treated rabbit erythrocytes. Agglutination was detected in 46 plants.

Since only a limited number of transformants could be analysed in the insect bioassay, four transgenic lines were randomly chosen for a more detailed analysis. To estimate the expression levels of the lectin, transgenic lines ( $\mathrm{T}_{1}$ generation) were analysed for lectin content by semiquantitative agglutination assays. The highest expression levels were observed for the transgenic lines APA-1 (pGPTV \#9848132-1-06, 3 copies of lectin gene inserted in genome) and APA-2 (pGPTV\#9848132-4-13, 1 copy of APA gene) in which the lectin accounted for 0.96 and $1.06 \%$ of the total soluble leaf protein, respectively (Table 1). The other two tobacco lines APA-3 (pGPTV\#9848132-4-16, 2 copies of APA gene) and APA-4 (pGPTV\#9848132-4-19, 1 copy of APA gene) exhibited markedly lower expression levels of recombinant lectin, representing 0.33 and $0.27 \%$, respectively, of the total soluble protein.

\section{Purification and characterisation of recombinant proteins}

Electrophoresis of crude leaf extracts from transgenic plants with high lectin expression revealed the presence of an extra band at the position of the lectin polypeptide (Fig. 2, lanes 4-5). Leaves of these transgenic tobacco plants were pooled and recombinant APA isolated. SDS-

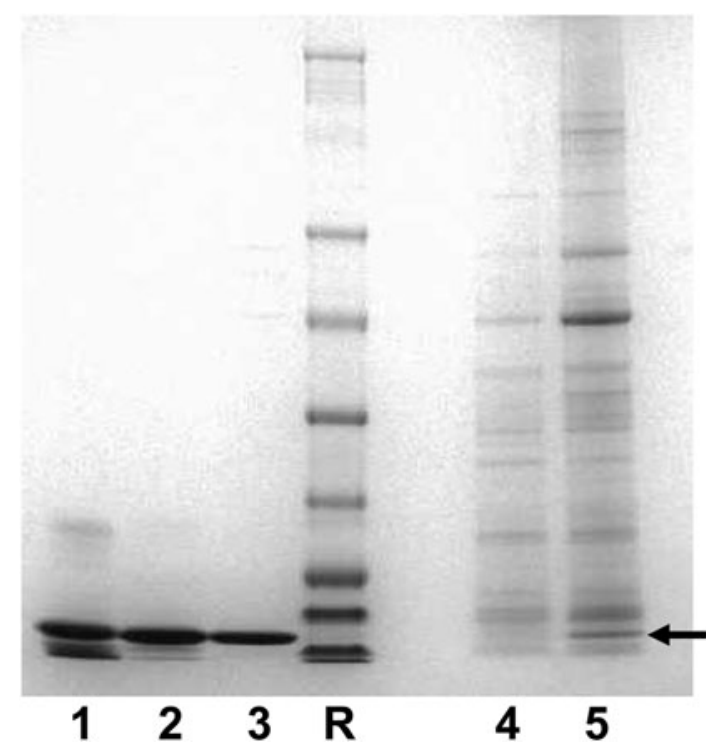

Fig. 2. SDS-PAGE of purified lectins and crude extracts from tobacco leaves. Lanes $1-3$ were loaded with $10 \mu \mathrm{g}$ of purified GNA, recombinant APA purified from tobacco and APA from leek, respectively. Lanes 4 and 5 were loaded with crude leaf extracts from control and transgenic plants (APA-1), respectively. The arrow indicates the position of the lectin polypeptide in the crude extract from the transgenic line. Lane $\mathrm{R}$ was loaded with molecular mass marker proteins: myosin $(191 \mathrm{kDa})$, phosphorylase (97 kDa), BSA (64 kDa), glutamic dehydrogenase (51 $\mathrm{kDa})$, alcohol dehydrogenase $(39 \mathrm{kDa})$, carbonic anhydrase $(28$ $\mathrm{kDa})$, myoglobin red $(19 \mathrm{kDa})$, lysozyme $(14 \mathrm{kDa})$ and aprotinin $(6 \mathrm{kDa})$. The gel was stained with Coomassie Brilliant Blue.

PAGE confirmed that the recombinant lectin was essentially pure and migrated with the same apparent $\mathrm{Mr}$ as APA prepared from leek leaves (Fig. 2, lanes 2-3). The recombinant lectin was further analysed by gel filtration on a Superose 12 column. As expected, the native and recombinant proteins eluted at the same position (data not shown). Hence it can be concluded that the recombinant APA also exists as a tetrameric molecule. Furthermore, $\mathrm{N}$-terminal sequencing of the recombinant proteins confirmed that tobacco cells successfully recognise and cleave the signal peptide at exactly the same position as in the parent plant. The N-terminal 15 amino acids determined for recombinant APA RNLLTNGEGLYAGQS are identical to the sequence of the native lectin. In addition, MS analysis revealed a lectin peak with a molecular mass of 12,239.8 $\pm 3.0 \mathrm{Da}$, which is in good agreement with the calculated mass of 12,237.0 Da for the mature APA.

TABLE 1. Absolute and relative lectin content of the leaves of wild type and transgenic tobacco plants, expressing APA.

\begin{tabular}{cccc}
\hline Transgenic line & $\begin{array}{c}\text { Lectin content } \\
(\mathrm{mg} / \mathrm{g} \mathrm{FW})\end{array}$ & $\begin{array}{c}\text { Mean total protein content } \pm \text { SEM } \\
(\mathrm{mg} / \mathrm{g} \mathrm{FW})\end{array}$ & $\begin{array}{c}\text { \% of total soluble protein } \\
\text { represented by APA }\end{array}$ \\
\hline APA-1 & 0.068 & $7.10 \pm 0.008$ & 0.96 \\
APA-2 & 0.091 & $8.55 \pm 0.269$ & 1.06 \\
APA-3 & 0.034 & $10.19 \pm 0.324$ & 0.33 \\
APA-4 & 0.023 & $8.42 \pm 0.070$ & 0.27 \\
Wild type & - & $5.62 \pm 0.107$ & - \\
\hline
\end{tabular}


A

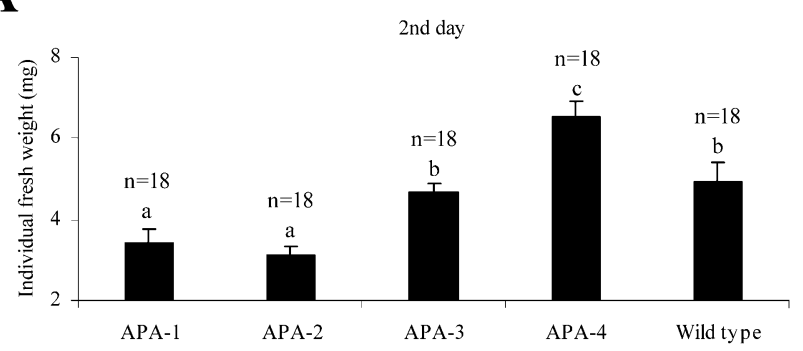

B

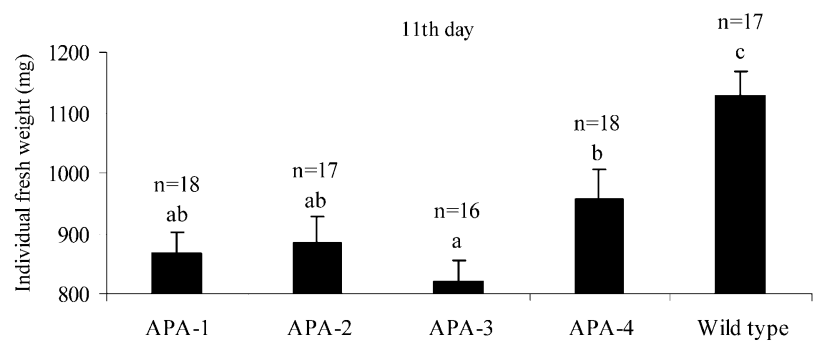

C

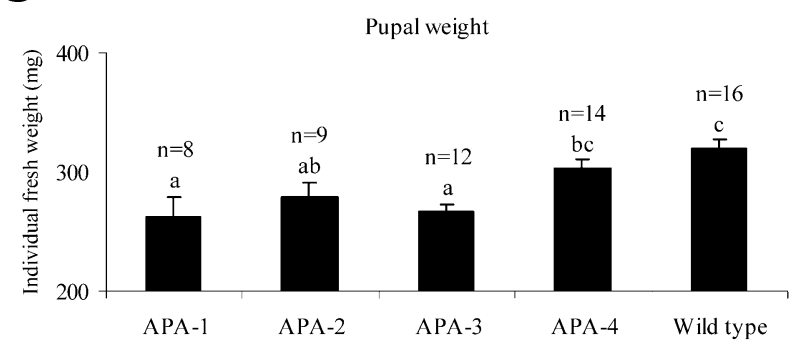

Fig. 3. Effect of ectopically expressed APA in leaves of transgenic tobacco plants on the weight gain of larvae of the cotton leafworm Spodoptera littoralis. Larvae were fed on detached leaves from control plants and transgenic lines APA-1, APA-2, APA-3 and APA-4. Panels A and B indicate the weight of the larvae on day 2 and 11, respectively. Pupal weight is shown in panel C. The data are expressed as means \pm SEM. At the start of the experiment, 18 second-instar larvae (per treatment, 3 randomly chosen replicate groups of 6 cages with each cage containing one larva) were selected for each transgenic line and wild type (control) tobacco plants. The number of individuals (n) for each treatment at each time point is given above the bar. ANOVA resulted in 3 groups for day $2(\mathrm{~F}=16.59 ; \mathrm{df}=4 ; \mathrm{p}<$ $0.001)$, in 3 groups for day $11(\mathrm{~F}=8.63 ; \mathrm{df}=4, \mathrm{p}<0.001)$ and in 3 groups for pupal weight $(F=7.73$; $d f=4 ; p<0.001)$. Different letters $(a-c)$ above columns indicate significant differences (post hoc Duncan test with $\mathrm{p}=0.05$ ).

\section{Insect bioassay with Spodoptera littoralis}

A selection of transgenic tobacco plants expressing different levels of APA (Table 1) was used in a series of bioassays to assess the possible insecticidal activity of the ectopically expressed lectin on 2nd-instar larvae of $S$. littoralis. The effect of lectin feeding delivered via transgenic leaf material on survival, growth and development of caterpillars was followed over a period of 4 weeks.

Feeding of 2nd-instar larvae of $S$. littoralis on leaves of the transgenic tobacco lines APA-1, APA-2, APA-3 and

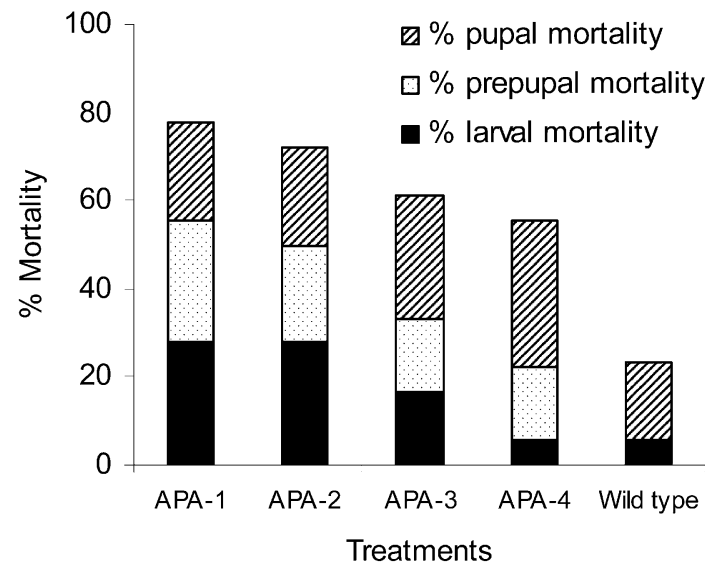

Fig. 4. Effect of ectopically expressed APA in leaves of transgenic tobacco plants on the survival of larvae, prepupae and pupae of the cotton leafworm Spodoptera littoralis. Typically, prepupal mortality was due to the formation of lethal larva-pupa intermediates. Larvae were fed on detached leaves from control plants and transgenic lines APA-1, APA-2, APA-3 and APA-4. The data are expressed as percentages of cumulative mortality at the moment that all individuals had pupated, i.e. day 17. At the start of the experiment, 18 second-instar larvae (per treatment, 3 randomly chosen replicate groups of 6 cages with each cage containing one larva) were selected for each transgenic line and wild type (control) tobacco plants.

APA-4 had a significant $(\mathrm{p}<0.05)$ negative effect on their weight gain. Reduction in larval weight gain was already apparent within 2 days of feeding on APA- 1 and APA-2 leaves (Fig. 3A). For APA-3 and APA-4, the growth inhibiting effect became apparent only after longer feeding periods. On day 11 , the weight of $S$. littoralis caterpillars fed on leaves of all four leek lectin expressing lines was $15-27 \%$ lower than that of the control caterpillars fed on wild type plants (Fig. 3B). Taking into account the challenged larval stages (L2-L6), 28\% of the larvae fed on APA-1 or APA-2 leaves died and did not reach the pupal stage (Fig. 4). For APA-3, this larval accumulated mortality percentage was $17 \%$, whereas APA-4 scored similarly as the control plants $(5 \%$ larval mortality).

Furthermore, lethal abnormalities were recorded in the prepupal stage with the formation of lethal larva-pupa intermediates. Insects fed on transgenic lines APA-1 and APA-2 had the most severe abnormalities and suffered mortalities of $27 \%$ and $22 \%$, respectively (Fig. 4). Prepupal mortality of insects fed on APA-3 and APA-4 lines was $16 \%$ in both cases, whereas there was no mortality in the control.

In addition to larval and prepupal mortality, APA also affected the metamorphosis process. Control larvae started to pupate on day 13 of the experiment: i.e., the percentage pupation was $25 \%, 44 \%$ and $100 \%$ on day 13 , 15 and 17, respectively (Fig. 5). Those larvae that fed on leaves of transgenic lines APA-1 and APA-2 survived and developed more slowly as none had pupated by day 13 and 15 , and only few had pupated by day 17 of the experiment. Similarly larvae fed on leaves of APA-3 also 


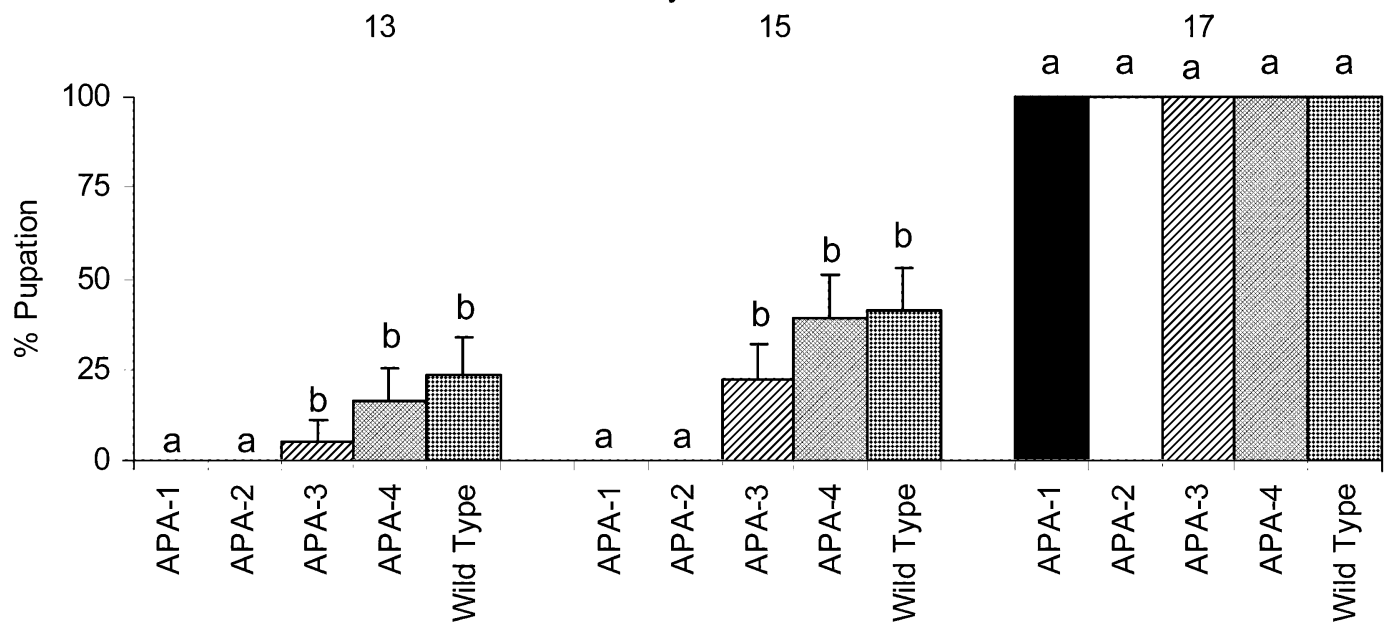

Fig. 5. Effect of ectopically expressed APA in leaves of transgenic tobacco plants on the percentage pupation of the cotton leafworm Spodoptera littoralis. Larvae were fed on detached leaves from control plants and transgenic lines APA-1, APA-2, APA-3 and APA-4. The data are expressed as means \pm SEM. At the start of the experiment, 18 second-instar larvae (per treatment, 3 randomly chosen replicate groups of 6 cages with each cage containing one larva) were selected for each transgenic line and wild type (control) tobacco plants.

developed more slowly with only $6 \%$ and $25 \%$ pupating on day 13 and 15 , respectively.

The other larvae that developed successfully when fed on APA-1, APA-2 and APA-3 pupated normally but were significantly $(\mathrm{p}<0.05 \%)$ lighter in weight $(80 \%)$ compared to the control pupae (Fig. 3C). All these pupae successfully produced adults as did the controls, indicating that adult emergence was not affected.

The total mortality over the 4 week period from 2 ndinstar larva to adult emergence, for larvae fed on APA-1, APA-2, APA-3 and APA-4 transgenic plants was 71, 64, 49 and $42 \%$ relative to that when they fed on the control that is after the application of Abbott's correction.

\section{DISCUSSION}

In the present study, we generated transgenic tobacco plants expressing the leek (Allium porrum L.) lectin gene. PCR, Southern blot and Western blot analysis confirmed the transgenic status of the different tobacco lines. A selection of plants was analyzed in more detail for lectin expression and insecticidal activity. Quantitative analysis of the lectin concentrations in four transgenic lines revealed important differences in lectin expression levels, ranging from 0.27 to $1.06 \%$ of the total protein in leaf tissue. The differential expression profile of APA observed between different lines might be due to position effects of the transgene integration in the plant genome.

Feeding the transgenic plants expressing APA to $S$. littoralis larvae resulted in a clear reduction in larval weight and a significant larval mortality, the severity of the effects apparently being dependent on the expression level of the transgene. Fitches et al. (1997) also report a 32 and $23 \%$ reduction in the larval biomass of the tomato moth L. oleracea fed on an artificial diet containing $2 \%$ GNA (w/w) and excised leaves of transgenic potato with GNA making up $0.07 \%$ of total soluble protein, respectively. In addition, they also show that GNA retarded larval development and affected pupation. A significant effect of GNA on larval survival was only recorded in a glasshouse experiment using transgenic potato plants (GNA expression $0.6 \%$ of total soluble protein), which resulted in a decrease in larval survival of approximately $40 \%$.

Remarkably, even the transgenic lines expressing the lowest lectin levels had clear insecticidal effects. Since APA negatively affected the weight gain during the larval stages, the development to the pupal stage was also retarded. It is a well-known phenomenon that last instar larvae need to reach a minimum critical fresh weight before pupating. Davidowitz et al. (2003) report that the critical weight is $55 \%$ of the peak larval weight of laboratory-reared larvae of the tobacco hornworm (Manduca sexta). Therefore, the observed retardation of metamorphosis of larvae fed on leaves of the transgenic APA lines might be due to an increase in the length of the feeding period required to reach the minimum critical fresh weight. However, it should be emphasized that the pupae produced by the caterpillars fed on leaves of the APA-1, APA-2 and APA-3 lines never attained the weight of control specimens, and accordingly yielded smaller adults. Similar results are recorded when $S$. littoralis is fed on transgenic tobacco plants overexpressing the garlic (Allium sativum) leaf (ASAL) and bulb (ASAII) lectins (Sadeghi et al., 2008).

It is suggested that the insertion of a foreign DNA fragment into the genome can knockout an endogenous gene that might affect the behaviour of the transgenic line.

At present we have no information on the mechanism(s) underlying the reduction in larval biomass caused by APA since there is no data on the possible occurrence of glycoconjugate targets for APA in the gut of S. littoralis. However, as in tomato moth Lacanobia (Fitches \& Gatehouse, 1998; Fitches et al., 2001) it is possible that the gut tissue of $S$. littoralis contains surface 
exposed glycoproteins that are recognized and bound by APA and this interaction eventually affects the nutrient uptake in the insect midgut or/and leads to a disruption of the midgut cell epithelium (Gatehouse et al., 1984; Eisemann et al., 1994). Additional support for such a mode of action comes from the observation that for the Griffonia simplicifolia lectin (GS-II) there is a clear correlation between receptor binding and toxicity towards the cowpea bruchid Callosobruchus maculatus (Zhu-Salzman et al., 1998). In addition, lectins may also act as a feeding deterrent leading to reduce food consumption. However, it is unknown at present if this is the case for certain lectins. Nonetheless, in future assays the effects of lectins on feeding behaviour and/or food consumption should be evaluated.

The present study demonstrates that ectopically expressed APA gives transgenic tobacco plants significant levels of protection against $S$. littoralis, which is considered a major pest insect as it causes severe yield losses in many economically important agricultural and horticultural crop plants. Taking into account the strong negative effects of APA on larval survival, growth and development the APA gene is certainly a promising candidate for crop protection purposes. Moreover, by virtue of its origin from a commonly used edible vegetable the use of this APA gene in transgenic crop plants might be less contentious.

ACKNOWLEDGEMENTS. A. Sadeghi is recipient of a doctoral grant from the Iran Ministry of Science, Research and Technology as well as Kurdistan University. E. Jurado-Jácome was supported by the Belgian Agency for Development and Cooperation (BADC) and CORPOICA funds (GGS IPMB M Sc programme). This research is supported by project 3G016306 of the Fund for Scientific Research (FWO-Vlaanderen, Brussels, Belgium). We are grateful for the help of C. Ripoll (INRA Versailles, France) with the Southern blot analysis.

\section{REFERENCES}

Аввотт W.S. 1925: A method of computing the effectiveness of an insecticide. J. Econ. Entomol. 18: 265-267.

Alford D.V. 2000: Pest and Disease Management Handbook. Blackwell Science, Oxford, $615 \mathrm{pp}$.

Becker D., Kemper E., Schell J. \& Masterson R. 1992: New plant binary vectors with selectable markers located proximal to the left T-DNA border. Plant Mol. Biol. 20: 1195-1197.

BRADFORD M.M. 1976: Rapid and sensitive method for quantitation of microgram quantities of protein utilizing principle of protein-dye binding. Anal. Biochem. 72: 248-254.

CHEN M.S. 2008: Inducible direct plant defense against insect herbivores: A review. Insect Sci. 15: 101-114.

Church G.M. \& Gilbert W. 1984: Genomic sequencing. Proc. Natl. Acad. Sci. USA 81: 1991-1995.

Czapla T.H. 1997: Plant lectins as insect control proteins in transgenic plants. In Carozzi N. \& Koziel M. (eds): Advances in Insect Control: The Role of Transgenic Plants. Taylor and Francis, London, pp. 123-138.

Davidowitz G., D'Amico L.J. \& Nishout H.F. 2003: Critical weight in the development of insect body size. Evol. Dev. 5: 188-197.

Desmyter S., Van Denbussche F., Van Damme E.J.M. \& PeuMANS W.J. 2001: Preparation of monospecific polyclonal antibodies against Sambucus nigra lectin related protein, a glycosylated plant protein. Prep. Biochem. Biotech. 31: 209-216.

Desmyter S., Van Denbussche F., Hao Q., Proost P., Peumans W.J. \& VAN DAMme E.J.M. 2003: Type-1 ribosomeinactivating protein from iris bulbs: a useful agronomic tool to engineer virus resistance? Plant Mol. Biol. 51: 567-576.

Eisemann C.H., Donaldson R.A., Pearson R.D., Cadogan L.C., Vuocolo T. \& Tellam R.L. 1994: Larvicidal activity of lectins on Lucilia cuprina mechanism of action. Entomol. Exp. Appl. 72: 1-10.

Fitches E. \& Gatehouse J.A. 1998: A comparison of the short and long term effects of insecticidal lectins on the activities of soluble and brush border enzymes of tomato moth larvae (Lacanobia oleracea). J. Insect Physiol. 44: 1213-1224.

Fitches E., Gatehouse A.M.R. \& Gatehouse J.A. 1997: Effects of snowdrop lectin (GNA) delivered via artificial diet and transgenic plants on the development of tomato moth (Lacanobia oleracea) larvae in laboratory and glasshouse trials. J. Insect Physiol. 43: 727-739.

Fitches E., Woodhouse S.D., Edwards J.P. \& Gatehouse J.A. 2001: In vitro and in vivo binding of snowdrop (Galanthus nivalis agglutinin; GNA) and jackbean (Canavalia ensiformis; Con A) lectins within tomato moth (Lacanobia oleracea) larvae; mechanisms of insecticidal action. J. Insect Physiol. 47: 777-787.

Gatehouse A.M.R., Dewey F.M., Dove J., Fenton K.A. \& Pusztal A. 1984: Effect of seed lectins from Phaseolus vulgaris on the development of larvae of Callosobruchus maculatus mechanism of toxicity. J. Sci. Food Agric. 35: 373-380.

Gatehouse A.M.R., Davison G.M., Newell C.A., Merryweather A., Hamilton W.D.O., Burgess E.P.J., Gilbert R.J.C. \& Gatehouse J.A. 1997: Transgenic potato plants with enhanced resistance to the tomato moth, Lacanobia oleracea: Growth room trials. Mol. Breed. 3: 49-63.

Hakim R.S., Blackburn M., Corti P., Gelman D., Goodman C., Elsen K., Loeb M., Lynn D. \& Smagghe G. 2007: Growth and mitogenic effects of arylphorin in vivo and in vitro. Arch. Insect Biochem. Physiol. 64: 63-73.

Horsch R.B., Fry J.E., Hoffmann N.L., Eichholtz D., Rogers S.G. \& Fraley R.T. 1985: A simple and general method for transferring genes into plants. Science 227: 1229-1231.

Huang F.N., Leonard B.R. \& Gable R.H. 2006: Comparative susceptibility of European corn borer, southwestern corn borer, and sugarcane borer (Lepidoptera: Crambidae) to Cry1 Ab protein in a commercial Bacillus thuringiensis corn hybrid. J. Econ. Entomol. 99: 194-202.

Jouanin L., Bonade-Bottino M., Girard C., Morrot G. \& Giband M. 1998: Transgenic plants for insect resistance. Plant Sci. 131: 1-11.

LAEMMLI U.K. 1970: Cleavage of structural proteins during assembly of head of bacteriophage-T4. Nature 227: 680-685.

MullerCohn J., Chaufaux J., Buisson C., Gilois N., Sanchis V. \& LERECLus D. 1996: Spodoptera littoralis (Lepidoptera: Noctuidae) resistance to CryIC and cross-resistance to other Bacillus thuringiensis crystal toxins. J. Econ. Entomol. 89: 791-797.

Murashige T. \& Skoog F. 1962: A revised medium for rapid growth and bioassays with tobacco tissue cultures. Physiol. Plant. 15: 473-497.

Sadeghi A., Smagghe G., Broeders S., Hernalsteens J.-P., De Greve H., Peumans W.J. \& Van Damme E.J.M. 2007: Expression of the garlic leaf lectin gene under the control of the phloem-specific promoter Asus1 from Arabidopsis thaliana protects against the tobacco aphid (Myzus nicotianae). Pest Manag. Sci. 63: 1215-1223. 
Sadeghi A., Smagghe G., Broeders S., Hernalsteens J.P., De Greve H., Peumans W.J. \& Van Damme E.J.M. 2008: Ectopically expressed leaf and bulb lectins from garlic (Allium sativum L.) protect transgenic tobacco plants against cotton leafworm (Spodoptera littoralis). Transgen. Res. 17: 9-18.

Sadeghi A., Van Damme E.J.M., Michiels K., Kabera A. \& SmagGHe G. (in press): Acute and chronic insecticidal activity of mannose-binding plant lectins towards pea aphids (Acyrthosiphon pisum) via artificial diet. Can. Entomol.

SAMBrooK J., Fritsch E.F. \& Maniatis T. 1989: Molecular Cloning: A Laboratory Manual. Cold Spring Harbor, New York, $1590 \mathrm{pp}$.

SAnchis V. \& Bourguet D. 2008: Bacillus thuringiensis: applications in agriculture and insect resistance management. A review. Agron. Sustain. Dev. 28: 11-20.

SAnger F., Nicklen S. \& Coulson A.R. 1977: DNA sequencing with chain-terminating inhibitors. Proc. Natl. Acad. Sci. USA 74: 5463-5467.

Sétamou M., Bernal J.S., Mirkov T.E. \& Legaspi J.C. 2003: Effects of snowdrop lectin on Mexican rice borer (Lepidoptera: Pyralidae) life history parameters. J. Econ. Entomol. 96: 950-956.

Sharma H.C., Sharma K.K. \& Crouch J.H. 2004: Genetic transformation of crops for insect resistance: Potential and limitations. Crit. Rev. Plant Sci. 23: 47-72.

Shelton A.M., Zhao J.Z. \& Roush R.T. 2002: Economic, ecological, food safety, and social consequences of the deployment of Bt transgenic plants. Annu. Rev. Entomol. 47: $845-881$.

Smagghe G., Decombel L., Carton B., Voigt B., Adam G. \& TIRRY L. 2002: Action of brassinosteroids in the cotton leafworm Spodoptera littoralis. Insect Biochem. Mol. Biol. 32: 199-204.

Smeets K., Van Damme E.J.M., Van Leuven F. \& Peumans W.J. 1997: Isolation, characterization and molecular cloning of a leaf-specific lectin from ramsons (Allium ursinum L.). Plant Mol. Biol. 35: 531-535.

Timmermans M.C.P., Maliga P., Vieira J. \& Messing J.C. 1990: The pFF plasmids - cassettes utilizing CaMV sequences for expression of foreign genes in plants. J. Bacteriol. 14: 333-344.

Van Damme E.J.M., Allen A.K. \& Peumans W.J. 1987: Isolation and characterization of a lectin with exclusive specificity towards mannose from snowdrop (Galanthus nivalis) bulbs. FEBS Lett. 215: 140-144.

Van Damme E.J.M., Goldstein I.J. \& Peumans W.J. 1991: A comparative study of mannose-binding lectins from the Amaryllidaceae and Alliaceae. Phytochemistry 30: 509-514.

Van Damme E.J.M., Smeets K., Engelborghs I., Aelbers H., Balzarini J., Pusztai A., Van leuven F., Goldstein I.J. \& Peumans W.J. 1993: Cloning and characterization of the lectin cDNA clones from onion, shallot and leek. Plant Mol. Biol. 23: $365-376$.

Van Damme E.J.M., Peumans W.J., Pusztai A. \& Bardocz S. 1998: Handbook of Plant Lectins: Properties and Biomedical Applications. John Wiley \& Sons, Chichester, 466 pp.

Van Deveire M., Smagghe G. \& Degheele D. 1996: Laboratory test method to evaluate the effect of 31 pesticides on the predatory bug, Orius laevigatus (Het: Anthocoridae). Entomophaga 41: 235-243.

VASCONCElos I.M. \& OliveIRA J.T.A. 2004: Antinutritional properties of plant lectins. Toxicon 44: 385-403.

Zhu-Salzman K., Shade R.E., Koiwa H., Salzman R.A., Narasimhan M., Bressan I.A., Hasegawa P.M. \& Murdock L.L. 1998: Carbohydrate binding and resistance to proteolysis control insecticidal activity of Griffonia simplicifolia lectin II. Proc. Natl. Acad. Sci. USA 95: 15123-15128.

Received June 20, 2008; revised and accepted September 26, 2008 